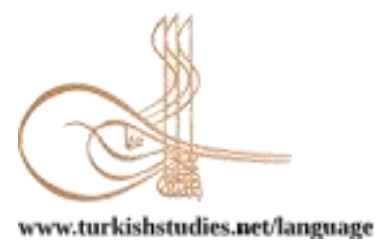

Turkish Studies - Language and Literature

eISSN: 2667-5641

Research Article / Araștırma Makalesi

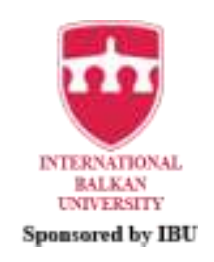

\title{
Kitâb-ı Dedem Korkut ve İkili Aşs Mesnevileri Üzerine Motiflerarası Bir Karşılaştırma
}

Kitâb-1 Dedem Korkut and a Two Love Mathnavises on an Inter-Motif Comparison

\author{
Timuçin Aykanat*
}

Gör Dedem Korkut Delâlî soylamış bin bir güher

Mesnevîler 'aşk-ı ulvîden sunar evlâ deger

\begin{abstract}
Kitâb-ı DedemKorkut, the great Turkish scholar Ord. Professor Dr. in the words of Mehmed Fuad Köprülü, it is worth more than half of all Turkish literature. On the other hand, the dual love mathnavi have taken their place in the development process of the novel concept as the narrative elements in classical Turkish literature. Stories of Dede Korkut and love mathnavies, which are two different cultural monuments, exhibit partnerships especially in the context of motifs. This study prepared by using the opportunities offered by comparative literature science; Kitâb-ı Dedem Korkut and the common motifs in the double love mathnavi and focuses on their analysis. In this direction. The works in two different categories were carefully scanned from the first line to the last line and the data obtained were processed with analysis-synthesis logic. This work is done without any distinction of being a product of folk literature or classical Turkish literature; showed how common they can be. This study, enriched with sample texts, facilitated the interpretation of the texts related to the headings. In the context of Kitâb-l Dedem Korkut and dual love mathnavi, motif of without children sultan, motif of adoption, naming motif, engagement in crib motif, motif of falling in love, struggle motif, imprisonment/closure motif, dream motif, hunt/hunting motif, deceit/counterfeit motif, disguise motif, minstrel test motif, formulistic numbers and dowry offering motifs were examined. After all; It was confirmed that the two narrative categories were common and identical in the context of their motives.
\end{abstract}

Structured Abstract: Science of Comparative Literature; at the national level, but mostly in the context of works written by different nations, by including almost all the elements that bring them into the body; by directing the researcher to think extensively on the existing products, in the framework of the benchmark of benchmarking; It is a systematic theory that provides the qualitative and quantitative development of interdisciplinary studies.

The Book of Dede Korkut is the oldest epic epic story of the Oghuz Turks. It consists of twelve epic stories and a preface. The stories it contains are products of oral traditions that are transmitted from language to language and from narrator to narrator throughout history. Stories were passed out from ear to ear, so they went beyond their true state. XV. It is presumed to be written in the second half of the century. It is a

\footnotetext{
* Dr. Öğr. Üyesi, Hakkâri Üniversitesi, Eğitim Fakültesi, Sosyal Bilimler ve Türkçe Eğitimi Bölümü Asst. Prof. Dr., Hakkâri University, Faculty of Education, Department of Social Sciences and Turkish Education ORCiD 0000-0000-0000-0000 https://orcid.org/0000-0003-1643-536X

timi_cin@hotmail.com

Cite as/ Atıf: Aykanat, T. (2020). Kitâb-1 Dedem Korkut ve ikili aşk mesnevileri üzerine motiflerarası bir karş1laştırma. Turkish Studies - Language, 15(2), 615-624. https://dx.doi.org/10.29228/TurkishStudies.40432

Received/Geliş: 06 January/Ocak 2020

Accepted/Kabul: 20 June/Haziran 2020

Checked by plagiarism software

Copyright $($ INTAC LTD, Turkey

Published/Yayın: 27 June/Haziran 2020

CC BY-NC 4.0
} 
resource that provides information on many subjects ranging from the life styles of Oghuzes to their economy, beliefs, dressing, feeding and the nature in which they live. One of the two manuscripts that survived is in the Dresden Library and one in the Vatican Library.

The Book of Dede Korkut is the magazine of epic Oğuz stories. Most of the twelve stories it contains are for the first time X.-XI. century, the old homeland of the Oghuz River Seyhun emerged on the length, XI. century, the Oghuz took over Iran, the South Caucasus and Anatolia and came to the Near East. The story of Bams1 Beyrek, also known as Alpamish, is given in V. It is dated to centuries.

Most of the stories pass through the two major rivers of Amit (Dicle nehri) in Eastern and Southeastern Anatolia and the branches of the Aras River in the vicinity of Kara Dere. In the story of Kanlı Koca Son Kan Turalı Boyu Trabzon, the area around Trabzon is clearly depicted.

$\mathrm{XV}$. the second half of the century is considered. It is estimated that the Akkoyunlu people who reigned around Kars and Erzurum had these epics written.

In the work, verse and prose are given together. Although the language shows the characteristics of the Azeri dialect, it is seen that not all language features belong to this dialect when compared with the present Azerbaijani dialect. There is an unnecessary literary style, short, simple expressions, untrue, sloppy style.

Dictionaries mathnavi forms a fictional narrative with a story in it. My story style While some of the mathnavi received narrative data under the title of story, some narrative data were shared. events and theses can be listed directly without this. On the other hand, he is a complete species. Although not, according to the topics covered love, heroism, religion, etc. the mathnavis in the context of various literary genres/genres.

The Mathnavis are fictional-narrative as traditional narrative jerseys. For mathnavi (with the exception of a number of examples created in the Historian style) it includes the pseudo-node-solution sections, which are almost all of the fictional narratives. Laying section, It is shaped by various literary genres and styles within the framework of traditional practices. Node section will form an arbitration in the context of narration and stylization features motifs are knitted. The solution section is; form of folk literature branch of traditional narrative forms it carries similar forms of ending with the narrative narratives, and, unlike them, complete a line of history shows. So this concept, which takes the name mathnavi, in addition to being a poetic form, it is an important classical art that provides form to fictional. It is a factor. Among the fictional narratives, the Mathnavis are included in the group of classical and traditional narratives. According to the topics he has studied, the most literary and the most they are undoubtedly the dual love mathnavies.

Accordingly; comparative literary science was introduced. Dede Korkut Stories were defined. Bilateral love mathnavi announced. The motif similarities between the two categories were shown. Also; In this direction; In the context of Kitâb-ı Dedem Korkut and dual love mathnavi, motif of without children sultan, motif of adoption, naming motif, engagement in crib motif, motif of falling in love, struggle motif, imprisonment/closure motif, dream motif, hunt/hunting motif, deceit/counterfeit motif, disguise motif, minstrel test motif, formulistic numbers and dowry offering motifs were examined. After all; It was confirmed that the two narrative categories were common and identical in the context of their motives.

As a result, two different work categories of the same cultural circle are common in terms of motifs. This jointness shows that they are on the same fictional plane and are nourished from the same sources.

Keywords: Kitâb-ı Dedem Korkut, The Dual Love Mathnavi, Comparative Literature Science, Motif, Narratives.

Öz: Kitâb-1 Dedem Korkut, büyük Türk âlimi Ord. Prof. Dr. Mehmed Fuad Köprülü’nün deyişiyle, bütün Türk edebiyatının yarısından fazla değerdedir. Öte yandan ikili aşk mesnevileri, klasik Türk edebiyatı içerisinde tahkiyevî anlatı unsurları olarak roman kavramının gelişim süreci içerisindeki yerini almıştır. İki ayrık kültürel abide konumunda yer alan Dede Korkut Hikâyeleri ve aşk mesnevileri, özellikle motifleri bağlamında ortaklıklar sergilemektedirler. Karşılaştırmalı edebiyat biliminin sunmuş olduğu olanaklardan yararlanarak hazırlanan bu çalışma; Kitâb-ı Dedem Korkut ve ikili aşk mesnevilerinde yer edinen ortak motifler ve onların çözümlenmesi üzerine yoğunlaşmıştır. İki ayrı kategoride yer alan eserler ilk satırından son satırına kadar özenle taranmış ve elde edilen veriler analiz-sentez mantığıyla işlenmiştir. Bu işlenmişlik,

Turkish Studies - Language, 15(2) 
tahkiyevî anlatıların halk edebiyatı ya da klasik Türk edebiyatı ürünü olma ayrımı olmaksızın; ne denli ortak olabildiklerini göstermiştir. Örnek metinlerle zenginleştirilen söz konusu çalışma, sunduğu madde başlarıyla ilgili metinlerin anlamlandırılmasını kolaylaştırdı. Bu doğrultuda; Kitâb-ı Dedem Korkut ve ikili aşk mesnevilerinde yer edinen, çocuğu olmayan padişah motifi, evlat sahibi olma motifi, ad verme motifi, beşikteyken nişanlanma/beşik kertmesi motifi, âşık olma motifi, mücadele motifi, hapsedilme/kaleye kapatılma motifi, rüya motifi, av/avlanma motifi, hile/karşıt gücü kandırma motifi, kılık değiştirme motifi, âşıklığın sınanması motifi, formulistik sayılar ve çeyiz sunma motifleri irdelendi. Sonuçta; tahkiyevî iki anlatı kategorisinin motifleri bağlamında ortak ve ayni iştiyak olduğu tescillendi.

Anahtar Kelimler: Kitâb-ı Dedem Korkut, İkili Aşk Mesnevileri, Karşılaştırmalı Edebiyat Bilimi, Motif, Tahkiyevî Anlatılar.

\section{Giriş}

\section{Karşılaştırmalı Edebiyat Bilimi}

Yeri geldiğinde ulusal düzlemde, ama çoğunlukla farklı ulusların yazdı̆̆ı eserler bağlamında, o eserleri vücuda getiren unsurların hemen tamamını konuya dâhil ederek; mevcut ürünler üzerinde kıyaslama temel ölçütü çerçevesinde incelemelerde bulunan, araştırmacıyı geniş çaplı düşünmeye yönlendirerek; disiplinler arası çalışmaların nitel ve nicel açılardan geliştirilmesini sağlayan sistemli bir kuramdır.

Temel ilkesi "karşılaştırma" olan bu kuram, Avrupa'da, bilim çağı olarak görülen XVIII. yüzyılın sonları ile XIX. yüzyılın başlarında ortaya çıkmıştır. 1795 yılında Goethe'nin Karşılaştırmalı Anatomi Yazısı (Erster Entwurf einer allgemeinen Einleitung in die Vergleichende Anatomie) yayınlanır. Eser, daha ilk cümlesiyle bu bilime önemli katkılar yapar. "Tabiat tarihi zaten karşılaştırmaya dayanır." (Aytaç, 2003a: 13). Bu bilimin temelinde Goethe'nin "Weltliteratur" dediği dünya edebiyatı düşüncesi yatar. Bu düşünce klasik eserlerin, insanlığın ortak edebiyat hazinesini yaratması anlamındadır. (Aytaç, 2003b: 15). Karşılaştırmalı çalışmalar ve bu bilim çevresinde yürütülen ilmi araştırmalar, elbette Goethe ile sınırlı değildir. Ancak Goethe, farklı ilim dallarında mukayese anlayışını yaygınlaştırmaya çalışan bilimadamlarının tezlerini de göz önünde bulundurarak, karşılaştırma anlayışını yazınbilimine yakınlaştırması ile önemlidir.

Türklük bilimi sahasında bu bilimin öncüleri arasında yer alan G. Aytaç, karşılaştırmalı edebiyat bilimi için "Edebiyat eserlerini inceleyen, araştıran edebiyat biliminin bir dalı, karşılaştırmalı edebiyat bilimidir. Görevi, işlevi, aynı dilde veya farklı dillerde yazılmış iki eseri konu, düşünce ya da biçim bakımından incelemek, ortak, benzer ve farklı yanlarını tespit etmek, nedenleri üzerinde yorumlar getirmektir." (Aytaç, 2003b: 13) şeklinde bir tanım yapar ve bir başka eserinde bu söylemine karşılaştırma "farklı dillere ait eserlere uygulandığında karşılaştırmalı edebiyat bilimi alanına girer." (Aytaç, 2003a: 18) biçiminde bir şerh koyar. Ayrıca G. Aytaç, "komparastiğin esprisi, birden çok eseri çalışma konusu yapmakla bakış açısını genişletmektir." (Aytaç, 1997: 72) diyerek bu yaklaşımın ne denli engin olduğunu ispat eder.

M. Andre Rousseau ve Claude Pichois tarafindan yazılan ve Dr. Mehmet Yazgan tarafından Türkçeye çevrilen Karşılaştırmalı Edebiyat isimli eser, sunduğu geniş bir tanım ve araştırmacıya rahat hareket etme firsatı ile anılmalıdır. Bu eser: "Karşılaştırmalı edebiyat; analoji, akrabalık ve etkileşim bağlarının geliştirilmesi suretiyle, edebiyatı diğer ifade ve bilgi alanlarına ya da zaman ve mekân içerisinde birbirine uzak veya yakın durumdaki olaylarla edebî metinleri birbirine yaklaştırmayı amaçlayan yöntemsel bir sanattır. Yeter ki bu edebî metinler, birçok dile ya da kültüre ait olsunlar; onları daha iyi tanımlayıp anlamak ve onlardan zevk alabilmek için aynı geleneğe ait bulunsunlar. Herkesin üzerine düşen, yalnızca kendi özel amacına ulaşmak için bu tanımdan kendisine yüzeysel ya da uygunsuz görünen yerleri çıkarıp atmasıdır." (Rousseau ve Pichois, 1994: 182). Öte yandan "Karşılaştırmalı edebiyat, sınırlı ve kesin bir alana uygulanan bir teknik değildir. Geniş ve çok yönlü oluşuyla hangi zaman ve zeminde olursa olsun, meraktan 
sentez zevkinden ve her türlü edebi gelişmeye açıklıktan meydana gelmiş bir ruh hâlini yansıtır." (Rousseau ve Pichois, 1994: 49) biçiminde kayıtlara yer vererek, ilgili bilimin anlaşılırlığını kolaylaştırmakta ve uygulama alanını genişleterek işlevselliğini arttırmaktadır.

\section{Dede Korkut Hikâyeleri Üzerine Anımsatmalar}

Dede Korkut Hikâyeleri, Oğuz halklarının IX-XI. yüzyıllar arası yaşanmışlıklarının XV. yüzyıl ortası itibariyle yazıya geçirilmiş olduğu önemli bir geçiş dönemi eseridir. Eser, bir mukaddime ve 12 hikâyeden ibarettir. Eserin Dresden ve Vatikan olmak üzere iki asli nüshas1 vardır.

Hikâyeler, hakkında Doğan Kaya, şunları söylüyor: “Dede Korkut Kitabı'nda yer alan hikâyeler manzum ve mensur bir yapıya sahiptir. Türkçe son derece başarılı kullanılmıştır. İfadeler destan üslubunda, akıcı, coşkulu ve ahenklidir. Üslup yapmacıktan uzak, açık, yalın ve kişindir. Türkçenin bu kadar başarılı kullanılması tesadüfi değildir. Bu, tekrar sözleri, asonans, aliterasyon, mecaz, cinas, özlü sözler, sıfatlar, atasözleri, deyimler ve secili cümlelerle sağlanmıştır. Bu bakımdan kimi yerlerde manzum-mensur ifadeler birbirine karışmıştır. Pek çok yerde manzum kısımlara "soylama" sözü ile geçilmiştir. Dede Korkut Kitabı, sıfatlar, kelime grupları, atasözleri, deyimler, dualar, beddualar, benzetmeler ve yakıştırmaların ustalıkla kullanılması özelliğiyle, Türkçe'nin bir edebiyat dili olmasının erken devirlerdeki en güzel örneğini teşkil eder. Manzum kısımlarda ölçülerde sağlamlık yoktur, ancak farklı hece kalıplarıyla ahenk sağlama başarısı gösterilmiştir. $\mathrm{Bu}$ başarıyı Türkçenin çağlar boyu işlene işlene bir edebiyat dili olmasına bağlayabiliriz." (www.dogankaya.com; E.T. 04.01.2020).

Kitâb-ı Dedem Korkut üzerine yapılan eser eksenli çalışmalar şu biçimdedir: 1916 yılında Kilisli Muallim Rifat (1876-1963), kitabın kopyasından istifade ederek Arap harfleriyle yayımlamıştır. Kilisli, kitabın basım macerası ile ilgili olarak bize şu bilgileri vermektedir: "Harb-i Umumî içinde Cenap Şehabeddin Bey Berlin'e kadar bir seyahat yapmış, orada İmparator Kütüphanesinde bu kitabı görmüş, fotoğrafını aldırmış, Maarif Nezaretine vermişti. Nezaret de Millî Tetebbular Encümenine gönderdi." Teodor Nöldeke'nin kopyası ettiği bu nüsha önce Ziya Gökalp'a verilmiş o da kopyayı bu işin uzmanı olan Kilisli Rıfat'a vermiştir. Orhan Şaik Gökyay (1902-1994), 1938'de kitabın ilk Lâtin harfleriyle baskısını gerçekleştirmiştir. Gökyay'ın kitabı dil ve halkbilimi açısında incelenerek yayımlanmış ilk eserdir. Bu çalışmaları M. Fahrettin Kırzıoğlu (1917-2005)'nun (1952), Muharrem Ergin'in (1958), Semih Tezcan-Hendrik Boeschoten (2001) ve Sadettin Özçelik' in çalışmaları ve binlerce makale izlemiştir. Azerbaycan'da da bu hususta önemli çalışmalar ortaya konulmuştur. Emin Abid 1930 yılında bir makale yayımlamış, Hamid Arasl1 1939 yılında ilk kitabı yayımlamıştır. Bu kitabı da E. Demircizade, Mehemmed Tehmasib, Samet Elizade, Şamil Cemşid'in çalışmaları izlemiştir. Dede Korkut Kitabı üzerine doktora tezi hazırlayan Muharrem Ergin (1923-1995) onu millî destan olma özelliği taşıyan bir abide eser olduğunu söyler.(Akt. Kaya, E.T. 04.01.2020).

\section{3. İkili Aşsk Mesnevileri Üzerine Anımsatmalar}

İkili aşk mesnevileri, geleneksel anlatı formaları olarak birer kurmaca-anlatı niteliği taşır. Zira bu mesneviler, kurmaca-anlatıların hemen tamamında olan serim-düğüm-çözüm bölümlerini içerir. Serim bölümü, gelenek hâlini almış uygulamalar çerçevesinde çeşitli edebî türler ve tarzlar ile şekillendirilir. Düğüm bölümü, öyküleme ve üslûplandırma özellikleri bağlamlarında tahkiyeyi oluşturacak motiflerle örülür. Çözüm bölümü ise; geleneksel anlatı formlarının halk edebiyatı kolunu oluşturan tahkiyevî anlatılarla benzer bitiş formellerini taşır ve onlardan farklı olarak genellikle hikâyenin tamamlandığını gösterir bir tarih mısra'ını barındırır.

Aynı anda bir nazım şekli aynı anda bir edebî tür olan mesneviye ilişkin şu görüşlerin paylaşılmasında da yarar vardır: "Osmanlı belagatinde türler, dizenin yapısına göre sınıflandırılmıştır; beyti (doğrusu yarım beyit olan mısrayı) temel tutarak tanımlanır. Mesnevi, kafiyeli beyitlerden oluşan nazım türüdür. Ama tür tanımlanırken konu da gözetilebilir. Mesnevi,

Turkish Studies - Language, 15(2) 
sırf kafiyeli-beyitli bir nazım türü değildir. Divan şiiri anlatısının büyük geleneğidir. Kafiyelibeyitli yazın, konu bakımından düşünüldügünde, aynı kategoriye sığdırılamayacak kadar birbirinden farklı anlatı türleri içerirmiş gibidir: Tıp üzerine risale; devlet kroniği; veliaht sünnet düğünlerinin tasvirleri; şehirli ayyarın, köftehor hayatının serüveni; aşk hikâyeleri -ama trajik olsun, komik olsun, kendi türünün parodisi de olsun hepsini içerir. Osmanlı edebiyatında bunların düzyazı örnekleri de vardır. Hâlbuki mesnevinin tarih boyunca gelişmesine özgü farkı, insanın başa çıkılamayacak iç halleriyle yüzleşip ciddi ve samimi olarak anlatmasıdır. Bildungsroman'ın atası modern öncesi romance'ın da özelliğidir bu. (...) Mesnevi sırf bir nazım türü değil, anlatının büyük geleneği olarak tanımlandığında, en azından adlarını duyduğumuz aşk hikâyelerinden ibaret olur: Leyla ile Mecnun, Ferhat ile Şirin, Yusuf ile Züleyha gibi tekrar tekrar yorumlanıp yazılan hikâyeler. Aşk yolunda olgunlaşma teması, bunlarla gelişir; bunlarla da çeşitli alegori türleri birleşir." (Holbrook, 1996: 73-74)

\section{Kitâb-ı Dedem Korkut ve İkili Aşk Mesnevilerinde Yer Alan Motiflerin Karşılaştırılması}

Karşılaştırmaya geçmeden önce; motif kavramının tanımlanmasında yarar vardır. En sade tanımlamayla motif, "Tek başına süs olarak kullanılan ve bir süslemeyi meydana getiren unsurlardan her biri ya da bir sanat eserinde s1k sik tekrarlanan unsur" (Ayverdi, 2005: 2096) olarak tanımlanabilir.

\section{a) Çocuğu olmayan Padișah/Yönetici Motifi}

Geleneksel anlatmaların hemen çoğunda ulu bir erkin varlığı bilinmektedir. Bilinen bir diğer olgu da söz konusu erkin bir türlü evlat sahibi olamaması durumudur. İki eser kategorisi de bu durumu etkin biçimde örnekler.

"Hanlar Hanı Bayındır Han, yine toy edip attan aygır deveden buğra koyundan koç kırdırmıştı. Bir yere ak otağ, bir yere kızıl otağ, bir yere de kara otağ kurdurmuştu. Kimin oğlu kızı yok kara otağa kondurun, kara keçeyi altına döşeyin, kara koyun yahnisinden önüne getirin. Yerse yesin, yemezse kalksın gitsin, dedi. Meğer Dirse Han derler bir beyin oğlu kızı yoktu."” (s. 78).

Hoca Mesud'un Süheyl ü Nevbahâr'ında yer alan Yemen Şahı, tüm çabalarına rağmen evlat sahibi olamamaktadır:

Bu kamusile oğlanı yoğidi

Anun gussası fikri key çoğidi $(389 / 220)^{2}$

\section{b) Evlat Sahibi Olma Motifi}

Evlat sahibi olma, geleneksel anlatmaların hemen çoğunda bir değişkenlik yaşanması sonucu gerçekleşmektedir. Hikâyeler' de; çocuğu bulunmayan Dirse Han, erdem gösterme, ziyafet verme ve hacet dileme sonucunda çocuk sahibi olabilmiştir. Dirse Han'ın Hatun'u eşine; "aç görsen doyur, çıplak görsen donat, borçluyu borcundan kurtar, tepe gibi et yığ, kımız sağdır, ulu toy eyle ve dilek dile. Ola ki bir ağzı dualının duası isabet eder ve evlat sahibi olursun" der. (s. 81). Nitekim Dirse Han, bu yolla çocuk sahibi olur.

Lârendeli Hamdî'nin Leylâ ve Mecnûn'u, çocuk sahibi olmayı, masalsı/fantastik bir motife bağlar:

Eline sundı bir ayvayı fi'l-hâl

${ }^{1}$ Dede Korkut Hikâyeleri'ne yönelik atıflar; Ergin, Muharrem (2004). Dede Korkut Kitabı. Ankara: TDK Yayınları. adlı çalışmadan hareketle sunulacak; metinler, anlaşılırlığı artık cümlelerle verilecektir. Gönderme, sadece sayfa numarasına yönelik olacaktır.

${ }_{2}^{2}$ İkili aşk mesnevilerine yönelik göndermeler, beyit/sayfa numarası biçiminde verilecektir. 
Giderdi şâhdan ay vâyı fi'l-hâl (778/441)

\section{c) Ad Verme Motifi}

İkili aşk mesnevilerinde ad verme ahvâle uygunluk esasına dayanır. Yûsuf-1 Meddâh'ın Varka ve Gülşâh'ında, "her birine ad veren ol üstad" tabirine denk gelinir. (76/128). Yine de en etkin örnek, Câmi' '̂’nin Vâmık u Azrâ' sında gözlemlenir:

Araşdurdı cihânı her bir âşık

Didiler ittifâkî ana Vâmık (754/512)

"Dedem Korkut gelip bu oğlana ad koysun, kucaklayıp babasına varsın, babasından oğlana beylik istesin taht alıversin dediler" (s. 82). Bunun nedeni, Dirse Han'ın oğlunun boğayı yenerek erliğini ispat etmesidir. Nitekim adı da Boğaçhan olacaktır.

\section{d) Beşikteyken Nişanlanma/Beşik kertmesi}

Türk yaşantısının bazı devirlerinde uygulanmış hâlen de uygulana gelen bir gelenektir. Her iki eser kategorisi de bu motife yer verir. Kitâb-ı Dedem Korkut'ta, Pay Püre Big ve Pay Piçen Big adına kalın Oğuz beyleri dua ederler. Onların er ve dişi birer çocuk sahibi olmalarını umarlar. Pay Piçen Big söyler: "Beyler Allah teala bana bir kız verecek olur ise benim kızım Pay Püre Big oğluna beşik kertme yavuklu olsun dedi.” (s. 117)

Şeyh Gâlib'in ölümsüz eseri Hüsn ü Aşk' ta bu hadiseyi kabile yerine getirir:

Re'y eylediler ki bu iki mâh

Birbirinin olalar hâh nâ-hâh (313/78)

e) Âşık Olma Motifi

İkili aşk mesnevilerinde âşı olma çeşitli biçimlerde gerçekleşir:

*Rüyada görerek âşık olma

*Birlikte alınan eğitim sürecinde âşık olma

*Görmeden âşık olma

*Surete (resim, nakş vs.) bakarak âşık olma

*Sesinden etkilenerek âşık olma

*Âşıklığına hayran kalarak âşık olma

*Görür görmez âşık olma

*Rastlaşarak âşı olma

*Zamanla gönül vererek âşık olma

*Kaza ve kaderin uygunsuz bir hükmü ile âşık olma

Ferahşâd'ın âşıklığına hayran kalarak ona âşık olan Hurşîd ü Bânû burada anılmalıdır:

Ne sevdâdan ki ol kişi delürdi

Dimagumda uş ol sevdâ belürdi (1976/202)

Kitâb-ı Dedem Korkut'ta durum biraz daha farklıdır ve şu ibarelerle geçer:

Göz açınca gördüğüm/gönül verip sevdiğim (s. 131) 


\section{f) Mücadele Motifi}

Kitâb-ı Dedem Korkut, çok çeşitli çekişmelerde doludur. Savaşçı bir toplum olan Türkler, Dede Korkut Hikâyeleri'nin yaşandığı devirlerde de kâfir illeri biçiminde adlandırdıkları topluluklarla savaş ve çekişme içindedirler. Bu esere şöyle yansır:

"Beri gelin kırk yoldaşım/Size kurban benim başım

Görür müsünüz Ağam Kazan baş kesti, kan döktü, beni seven yiğitlerim ne durursunuz, kâfirlerin bir ucunu tepelim dedi." (s. 163)

İkili aşk mesnevilerinde en etkin mücadele örneği, Süheyl ü Nevnahâr'da Nevbahâr'ın esaretten kurtulmak için verdiği mücadeledir:

Bilezükden üşenür iken kolı

Nite balta salmaga vard1 eli (1970/3227)

\section{g) Hapsedilme/Kaleye Kapatılma Motifi}

İkili aşk mesnevilerinde; Hz. Yûsuf'un kuyuya atılması vakıası ile başlayan ve esir alma, kaleye kapatma, eve kapatma biçimlerinde örneklenen motif, Kitâb-ı Dedem Korkut'ta ölümü sembolize eder:

Tekür'ün Karısı: 'Kazan Bey! Nedir hâlin, dirliğin yer altında mı yeryüzünde mi hoştur? Hem şimdi ne yersin, ne içersin, neye binersin? Dedi. Kazan söyledi: Ölülerinize aş verdiğiniz vakit ellerinden alırım hem de ölülerinizin sırtına binerim, dedi. Tekür'ün Karısı: Kazan Bey yedi yaşında bir kızım ölmüştür, sakın ona binme, dedi. (s. 235).

\section{h) Rüya Motifi}

Rüya, manevi âlemlerin ilhamıdır. Kutadgubilig'e göre de bir bilene sorulmalıdır. Rüya iyiye yorulursa, sonucu iyi çıkar. Her iki eser kategorisi de bu motife yer verir.

İkili aşk mesnevileri arasında Hüsn $\ddot{u}$ Aşk ile birlikte eşsizliğini koruyan Leylâ ve Mecnûn/Fuzûlî bu motifi, Zeyd'in âşıkların akıbetlerini öğrenmesi duyarlılığı üzerinden işler:

Menzilleri oldı bâğ-1 rıdvân

Çâkerleri oldı hûr u gilmân (3030/502)

Rüya, uyku ile alakalıdır. Oğuzların yedi gün uyuduklarını anmış olalım. "Meğer Han'ım o gece kalın Oğuz'un devleti Bayındır Han'ın güveyisi, Ulaş Oğlu Salur Kazan kara kaygılı vakı gördü. Esnedi, aya kalktı ve söyledi..." (s. 99)

\section{1) Av/Avlanma Motifi}

Türkler, eski devirlerden bu yana avlanmaya düşkün topluluklardır. Şimdilerde eğlenceye dönüşen avlanma, eski Türk yaşantısında eğitim ve savaşa hazırlık mahiyeti taşımaktaydı. İkili aşk mesnevilerinde avlanma, her zaman olağan bir av amacı taşımaz. Bu unsur; kimi zaman bir hile, kimi zaman savaşa hazırlık, kimi zaman esas kahramanı teskin edicilik, kimi zaman da bağlı bulunduğu ortamdan sıyrilıp kurtulmak için bahane üretme vb. gayelere yöneliktir. Kitâb-ı Dedem Korkut'ta av, "yata yata yanımız ağrıdı, dura dura belimiz kurudu, yürüyelim ey beyler! Av avlayalım, kuş kuşlayalım” (s. 95) ibareleri ile geçer.

\section{i) Hile/Karşıt Gücü Kandırma Motifi}

Kitâb-ı Dedem Korkut'ta hile motifi, Yalancı Oğlu Yaltaçuk üzerinden görülür. Yaltaçuk, Bams1 Beyrek'in kendisine vermiş olduğu gömleği kana bulayarak Beyrek'in öldüğüne herkesi inandırır ve Beyrek'in sevdiği kız olan Banı Çiçek ile evlenmek ister. Hile motifi, ikili aşk 
mesnevilerinden Mihr ü Mâh/Zarîfî'da içki ve kadın üzerinden örneklenir. Mesnevinin müellifi, dini bütün bir şahsiyet olarak tanıttığ1 Mâh'1 yenik düşürmez. $(475,476 / 123)$.

\section{j) Kılık Değiştirme Motifi}

$\mathrm{Bu}$ motif, masal ve efsane türü anlatılarda yer edinen yerine geçme motifi ile karıştırılmamalıdır. Kılık değiştirmede başka bir surete bürünme söz konusu olabilse de başka bir kahramanın yerine geçme yoktur. Kitab-ı Dedem Korkut'ta, Banı Çiçek ve Bamsı Beyrek'in aşkının işlendiği hikâye, bu motife örnek oluşturur. Bamsı Beyrek, dostu ve düşmanının kim olduğunu öğrenmek için ozan k1lığına girer. (s. 142). İkili aşk mesnevilerinde; Şî̂in'i daha fazla bekleyemeyen Hüsrev, tebdil-i kıyafet onu ziyaret eder. Muhatabınca tanınmayan Hüsrev, hüsrana uğrar. (1809/66).

\section{k) Âşıklığın Sınanması Motifi}

İkili aşk mesnevilerinde en etkin örnek, Yûsuf-1 Meddâh'ın Varka ve Gülşâh'ında yer alan ve rakip konumunda bulunan Muhsin Şah'ın yaptığıdır:

İmtihân eyler bularun '1şkını

Kim mecâzi yâ hakîki mi anı (1414/262)

Kitâb-ı Dedem Korkut, bu bapta çokça etkin bir örnek verir. Bu sınama, muhatapların evlilik nişanları olacaktır:

"Senin atın benim atımı geçerse, onu da geçersin, senin okun benim okumu geçerse onu da geçersin, hem seninle güreşelim, beni basarsan onu da basarsın dedi." (s. 123)

\section{l) Formulistik Sayılar}

Aynı değer yargılarına sahip eserlerin değerleri de içkinlik bağlamında aynı olacaktır. Bu itibarla Oğuzların yedi gün uyuduklarını ve kırk yiğit ile kırk güzele sahip olduklarını analım. Öte yandan Deli Karçar'ın istediği çeyizin, biner adet olması da dikkat çekicidir. İkili aşk mesnevilerinde aynı formulistik sayılara denk gelinmektedir. Anlatılarda her zaman beliren bir şah/padişah, iki kabile, iki kardeş, dört kutlu nesnenin ere hediye edilmesi, aşılacak olan kalenin beş kapısının bulunması vb. hususlar bu durumu örnekler.

\section{m) Çeyiz Motifi}

İkili aşk mesnevilerinde daha çok hediye verme bağlamında karşımıza çıkan çeyiz motifi, Kitâb-ı Dedem Korkut'ta hayli muteber ve değişiktir. "Bin buğra getirin, maya görmemiş olsun. Bin aygır getirin kısrağa aşmamış olsun. Bin koyun görmemiş koç getirin. Bin kuyruksuz kulaksız köpek getirin. Bin de pire getirin, bana dedi." (s. 127).

\section{Sonuç}

Motif, bir eseri ören biricik unsurdur. Motiflerin sayısı arttıkça bu biriciklik çokluk, çok örgülülük ve çok katmanlılığa dönüşür. Bir kültüre ait hemen her eser benzeri motiflerle örülüdür. Ne mahsulü olursa olsun; eserlerde yer edinen müşterek motiflilik, eserlerin müştereklik çizgisini netleştirecektir. Biri halk edebiyatına ve diğerleri klasik Türk edebiyatına ait iki eser kategorisi, motifleri bağlamında değerlendirildi. Bu doğrultuda; iki eser kategorisi, karşılaştırmalı edebiyat bağlamında ve motiflerarası olarak tahlil edildi. Ayni kültüre ait söz konusu eserlerin, aynı bağlamda yer aldıkları ve kategori farkına rağmen müşterek bulundukları saptandı. Metin örneklemelerinden hareketle iki eser kategorisinin farklı kurgu ve üsluplarda benzeri şeyleri söyledikleri ortaya kondu. Değer yargılarının eserlerin oluşum ve ortaya konma serüvenlerine ne denli etki yaptığı gözlemlendi. Bu itibarla; Kitâb-ı Dedem Korkut ve ikili aşk mesnevilerinde yer edinen;çocuğu olmayan padişah motifi, evlat sahibi olma motifi, ad verme motifi, beşikteyken nişanlanma/beşik kertmesi motifi, âşık olma motifi, mücadele motifi, hapsedilme/kaleye kapatılma 
motifi, rüya motifi, av/avlanma motifi, hile/karşıt gücü kandırma motifi, kılık değiştirme motifi, âşıklığın sınanması motifi, formulistik sayılar ve çeyiz sunma motifleri etkin örneklerle birlikte ifşa edildi. Neticede; kültürel değerlerin tetkikine bir rol-model daha eklendi.

\section{Kaynakça}

Ahmedî (1975). Cemşî̀d ü Hurşî̀d İnceleme-Metin. (Haz. Mehmet Akalın), Ankara: Sevinç Matbaasi.

Aytaç, Gürsel (1997). Karşılaş̧ırmalı Edebiyat. Ankara: Gündoğan Yayınları.

Aytaç, Gürsel (2003a). Karşılaştırmalı Edebiyat Bilimi. İstanbul: Say Yayınları.

Aytaç, Gürsel (2003b). Genel Edebiyat Bilimi. İstanbul: Say Yayınları.

Ayverdi, İlhan (2005). Misalli Büyük Türkçe Sözlük. (I-III), İstanbul: Kubbealtı Vakfı Yayınları.

Bekâyî (2003). Mensûr Süheyl ü Nevbahâr İnceleme-Metin-Sözlük. (Haz. Selami Ece), Erzurum: Aktif Yayınevi.

Ergin, Muharrem (2004). Dede Korkut Kitabı. Ankara: TDK Yayınları.

Fuzûlî (1996). Leylâ ve Mecnûn Metin, Nesre Çeviri, Notlar ve Açıklamalar. (Haz. Muhammed Nur Doğan), İstanbul: Çantay Kitabevi.

Hâşimî (1996). Tahkiye Açısından Hâşimî’nin Mihr üVefâ Mesnevîsi Transkripsiyonlu MetinInceleme. (Haz. Selami Ece), Yayımlanmamış Yüksek Lisans Tezi, Erzurum: Sosyal Bilimler Enstitüsü.

Holbrook, Victoria (1996). “Alegorinin Ölümü, Hüsn-ü Aşk’ın Özgünlügüu”. Defter, S.27, s. 65-80.

Kıyâsî (2007). Klyâsî’nin Mihr ü Mâh Mesnevîsi. (Haz. Dilek Aksoylu), Yayımlanmamış Yüksek Lisans Tezi, Kocaeli: Sosyal Bilimler Enstitüsü.

Lâmi'î (1998). Vâmık u Azrâ İnceleme-Metin. (Haz. Gönül Ayan), Ankara: AKM Yayınları.

Lâmi'î (2009). Lâmi'i Çelebi’nin Veyse vü Ramin Mesnevisi Inceleme-Metin-Sadeleştirme. (Haz. Murat Öztürk), Yayımlanmamış Doktora Tezi, Erzurum: Sosyal Bilimler Enstitüsü.

Lârendeli Hamdî (2002). Lârendeli Hamdî’nin Leylâ vü Mecnûn Mesnevîsi İnceleme/Metin ve Diğer Leylâ vü Mecnûn Mesnevîleriyle Mukâyesesi. (Haz. Rıfat Kütük), Yayımlanmamış Doktora Tezi, Erzurum: Sosyal Bilimler Enstitüsü.

Manisalı Câmi'î (2002). Manisalı Câmi'î'nin Vâmık u Azrâ Mesnevîsi İnceleme-MetinSadeleştirme. (Haz. Selami Ece), Yayımlanmamış Doktora Tezi, Erzurum: Sosyal Bilimler Enstitüsü.

Mes'ûd Bin Ahmed (1991). Süheyl ü Nevbahâr Inceleme-Metin-Sözlük. (Haz. Cem Dilçin), Ankara: AKM Yayınları.

Mu'îdî (2009). Kalkandereli Mu'îdî’nin Şem ü Pervâne Mesnevîsi. (Haz. Nihal Kara),Yayımlanmamış Yüksek Lisans Tezi, Kocaeli: Sosyal Bilimler Enstitüsü.

Rousseau, M. Andre ve Pichois Claude (1994). Karşılaştırmalı Edebiyat. (Çev.: Mehmet Yazgan), İstanbul: MEB Yayınları.

Şeyh Gâlib (2003). Hüsn ü Aşk Metin, Nesre Çeviri, Notlar ve Açılamalar. (Haz. Muhammed Nur Doğan), İstanbul: Ötüken Yayınları. 
Şeyhî (1963). Hüsrev ü Şî̀n İnceleme-Metin. (Haz. Faruk Kadri Timurtaş), İstanbul: İstanbul Üniversitesi Yayınları.

Şeyhoğlu Mustafa (1979). Hurşîd-Nâme (Hurşîd ü Ferahşâd) Inceleme-Metin-Sözlük-Konu Dizini.(Haz. Hüseyin Ayan), Erzurum: Atatürk Üniversitesi Basımevi.

Şeyyâd Hamza (2008). Yûsuf u Zelîhâ/Destân-ı Yûsuf Giriş-İnceleme-Metin-Dizinler. (Haz.Osman Yıldız), 2. Baskı, Ankara: Akçağ Yayınları.

Yûsuf-1 Meddâh (2007). Varka ve Gülşah. (Haz. Kâzım Köktekin), Ankara: TDK Yayınları.

Zârifî (1995). Zârifì ve Mihr ü Mâh Mesnevîsinin Tenkitli Metni İle İncelenmesi. (Haz. Vedat Nûri Turhan), Yayımlanmamış Yüksek Lisans Tezi, Erzurum: Sosyal Bilimler Enstitüsü.

www.dogankaya.com; (E.T. 04.01.2020). 